\title{
Psychometric Properties and Measurement Invariance of the Arabic Version of the Flourishing Scale
}

\author{
Saeed Abdullah AL-Dossary ${ }^{1}$ \\ ${ }^{1}$ Psychology Department, College of Education, University of Ha'il, Ha'il, Saudi Arabia \\ Correspondence: Saeed AL-Dossary, Psychology Department, College of Education, University of Ha'il, Ha'il \\ P.O. Box 1818, Saudi Arabia. \\ Received: March 22, 2021 \\ Accepted: April 13, 2021 \\ Online Published: April 21, 2021 \\ doi:10.5539/ijps.v13n2p20 \\ URL: https://doi.org/10.5539/ijps.v13n2p20
}

\begin{abstract}
The flourishing Scale (FS) is a measure of overall life well-being. The aim of the study was to assess the psychometric properties and measurement invariance of the Arabic version of the FS in the Saudi Arabian context. Data was collected from two samples: 969 students at two universities and 299 full-time employees working in multiple sectors. Internal consistency of the FS was examined by calculating Cronbach's alpha coefficient to test relaibility. To evaluate convergent and discriminant validity, the FS was compared with other measures of well-being, happiness, and depression. In order to examine the factor structure and the measurement invariance of the FS across study samples, confirmatory factor analysis and multi-group confirmatory factor analysis were performed. The FS showed good internal reliability as well as convergent and discriminant validity. Results also provided support for a one-factor and an invariant structure of the FS. Taken together, these results suggest that the FS Arabic version is a reliable and valid measure for the Arabic cultural context.
\end{abstract}

Keywords: positive psychology, flourishing scale, psychological well-being, measurement invariance, subjective well-being, psychometric properties

\section{Introduction}

Psychology has traditionally mostly focused on illnesses and negative sides of human life and experiences such as fear, depression, and learning disability (Seligman \& Csikszentmihalyi, 2000). Nevertheless, in neoteric decades, the focus has changed to positive psychology, which examines the positive sides of human life and experiences. A central focus of positive psychology is the concept of well-being (Keyes, Shmotkin, \& Ryff, 2002; Seligman, 2011). It is a complex, multifaceted concept and has been defined and measured in the literature from two theoretical perspectives, namely hedonic and eudemonic well-being (Ryan \& Deci, 2001). The hedonic perspective, frequently know as subjective well-being (SWB), focuses on subjective happiness with pleasure and enjoyment (Waterman, 2008), and therefore defined well-being basically with regards to gratification achievement and pain avoidance. However, eudemonic perspective, also referred to as psychological well-being (PWB), argues that well-being is more than just happiness, and deems self-realization, meaning in life, and personal growth, to be essential for well-being (Ryan \& Deci, 2001).

Different scales of well-being established on these two perspectives have been developed (Diener, Oishi, \& Lucas, 2003). For example, scales frequently used to evaluate hedonic view involving the Satisfaction with Life Scale (Diener, Emmons, Larsen, \& Griffin, 1985), the Positive and Negative Affect Schedule (Watson, Clark, \& Tellegen, 1988), and the Subjective Happiness Scale (Lyubomirsky \& Lepper, 1999). Most widely used scales established on the eudemonic belief involving the Scales of Psychological Well-Being (Ryff \& Keyes, 1995) and the Basic Needs Satisfaction Scale (Ryan \& Deci, 2001). Recent efforts have found that well-being can be best conceptualized as a multidimensional phenomenon that covers aspect of both perspectives of well-being (Deci \& Ryan, 2008). Based on these efforts, Diener et al. (2010) created a new measure titled the Flourishing Scale (FS).

The FS has been validated in different contexts and translated into various languages around the world, including Chinese (Duan \& Xie, 2019; Tang, Duan, Wang, \& Liu, 2016; Tong \& Wang, 2017), Dutch (Schotanus-Dijkstra et al., 2016), French (Villieux, Sovet, Jung, \& Guilbert, 2016), Italian (Giuntoli, Ceccarini, Sica, \& Caudek, 2017), Japanese (Sumi, 2014a; Sumi, 2014b), Mandarin (Lin, 2015), Persian (Fassih-Ramandi, Soleimani, Allen, Gorgulu, \& Motalebi, 2020; Khodarahimi, 2013), Portuguese (da Fonseca, da Silva, Macedo, Vione, \& Veloso, 2015; Silva \& Caetano, 2013), Russian (Didino, Taran, Barysheva, \& Casati, 2019), Spanish (Checa, Perales, \& 
Espejo, 2018; Pozo-Munoz, Garzon-Umerenkova, Bretones-Nieto, \& Ligia-Charry, 2016; Ramires-Maestre et al., 2017), and Urdu (Choudhry et al., 2018). It has been found to have well-established psychometric properties in these validation studies. However, research of well-being is still limited in Arabic context (Al-Darmaki et al., 2015). To date, there is only one study conducted by Salama-Younes (2017) that tested the FS among university student samples in Egypt. However, there are significant cultural differences and languages specificities between Saudi Arabia and Egypt and the application of a transcribed scale into Arabic may not be parallel in both countries. Moreover, the reliability and validity of the FS Arabic version was only evaluated based on student samples, therefore the measurement invariance of the scale has not been assessed between student and non-student samples. Testing of measurement invariance is a crucial aspect of scale validation since it allows valid comparisons and interpretations to be made between groups (Putnick \& Bornstein, 2016). Therefore, the aim of the study was to assess the psychometric properties and measurement invariance of the Arabic version of the FS in two samples of university students and full-time employees in the Saudi context.

\section{Method}

\subsection{Participants and Procedure}

Data was collected from two samples, one of university students and one of full-time employees, in Saudi Arabia. An online survey designed on Google form was distributed via an online link in an email to the participants between 25 December 2020 to 21 January 2021. The total number of participants of both samples was 1268, of whom $58.1 \%(\mathrm{~N}=737)$ were females. The student sample consisted of 969 undergraduate and postgraduate students from two universities, namely Saudi Electronic University and Qassim University. Most students were females $(640,66 \%)$ and their ages ranged from 20 to 57 years old $(M=28.63, \mathrm{SD}=6.37)$. The students were from several different colleges, including business administration, health sciences, computer sciences, law, and social sciences. The employee sample consisted of 299 individuals working in various sectors such as hospitals, schools, and banks. Most employees were males (202, 67.6\%), were married (209,69.9\%). Less than half of employees were aged between 25-34 years (43.1\%), followed by the 35-44 year age group (34.5\%), and the 45-54 year age group (17.4\%). Few employees $(5 \%)$ were over the age of 55 years. The range of their working experience was 1 to 40 years $(\mathrm{M}=13.43, \mathrm{SD}=8.81)$. All participants were informed about the purpose of the study and were given the right to remain anonymity. All participants completed the demographic items and the FS, along with other measures. Two staff members of the English department at Hail University translated the measures from English to Arabic. Following that, they were translated back to English to verify the accuracy of the translations.

\subsection{Measures}

Flourishing Scale (FS). The FS is an 8-item measure of positive aspects of human functioning such as relationships, self-esteem, meaning and purpose of life, and optimism (Diener et al., 2010). Items were scored on a 7-point Likert scale starting from 1 (strongly disagree) to 7 (strongly agree). Examples of these items include "I lead a purposeful and meaningful life" and "I am a good person and live a good life". Total scores range from 8 to 56 with higher scores indicating greater levels of positive psychological functioning.

Satisfaction with Life Scale (SWLS). The SWLS is a 5-item measure of worldwide satisfaction with different aspects of life (Diener et al., 1985). Items were scored on a 7-point Likert scale ranging from 1 (strongly disagree) to 7 (strongly agree). Example of these items include; "In most ways my life is close to my ideal" and "The conditions of my life are excellent". Total scores range from 5 to 35, with higher scores indicating greater levels of life satisfaction.

The Centre of Epidemiological Studies Depression Scale (CES-DS). The CED-DS is an 8-item measure of the frequency of depressive symptomatology including depressive affect, sadness, loneliness, and sleep disturbance (Radloff, 1977). Items were scored on a 4-point Likert scale ranging from 0 (non or almost none of the time), 1 (some of the time), 2 (most of the time), to 3 (all or almost all of the time), with the two positively phrased items "I enjoyed life" and "I was happy" were reverse scored. Total scores range from 0 to 24 , with higher scores indicating greater depressive symptomatology.

Happiness $(H)$. Happiness was measured with a Fordyce's (1988) one item measure of general happiness, "Taking all things together, how happy would you say you are?" This item was scored on an 11-point scale ranging from 0 (extremely unhappy) to 10 (extremely happy).

Life Satisfaction (LS). Life satisfaction was assessed with one item measure from the World Values Survey (OECD, 2013). The item "All things considered, how satisfied are you with life as a whole nowadays?" was scored on a sacle of 11 points ranging from 0 (extremely dissatisfied) to 10 (extremely satisfied). 


\subsection{Data Analysis}

Descriptive statistics of the FS were calculated and reliability was obtained using internal consistency by calculating Cronbach's alpha coefficient. Confirmatory factor analysis (CFA) and multi-group confirmatory factor analysis (MGCFA) were conducted to test the facture structure and the measurement invariance of the FS across study samples. To assess convergent validity, the FS was correlated with other measures of well-being and happiness: Fordyce's one item of happiness; Satisfaction with life scale; and one item satisfaction with life. Discriminant validity was tested by calculating the correlation between the FS with the CES-DS. Data analyses were performed using SPSS 26.0 and Amos 24.0.

\section{Results}

\subsection{Descriptive Analysis and Internal Consistency}

The means, standard deviations, range of scores, and internal consistency are presented in Table 1 for the FS in the two samples. University students had a slightly lower level of flourishing than employees. Student's mean score was $5.66(\mathrm{SD}=0.99)$ with a range from 1 to 7 . For the employee sample, the mean score on the FS was $6.07(\mathrm{SD}=0.71)$ with a range from 3 to 7 . The FS had good internal consistency in both samples, with Cronbach's alpha values equal to 0.87 and 0.84 in the student and employee samples, respectively.

Table 1. Descriptive statistics, internal consistency, and factor loading for the Arabic Flourishing Scale across study samples

\begin{tabular}{|c|c|c|c|c|}
\hline \multirow[b]{2}{*}{ Flourishing scale } & \multicolumn{2}{|c|}{ Student sample $(\mathrm{N}=969)$} & \multicolumn{2}{|c|}{ Employee sample $(\mathrm{N}=299)$} \\
\hline & Mean (SD) & $\begin{array}{l}\text { Standardized factor } \\
\text { loading }\end{array}$ & Mean (SD) & $\begin{array}{l}\text { Standardized factor } \\
\text { loading }\end{array}$ \\
\hline I lead a purposeful and meaningful life & $5.63(1.39)$ & 0.76 & $5.91(1.13)$ & 0.78 \\
\hline $\begin{array}{l}\text { My social relationships are supportive } \\
\text { and rewarding }\end{array}$ & $5.08(1.50)$ & 0.71 & $5.82(1.07)$ & 0.75 \\
\hline $\begin{array}{l}\text { I am engaged and interested in my daily } \\
\text { activities }\end{array}$ & $5.11(1.53)$ & 0.73 & $5.65(1.23)$ & 0.66 \\
\hline $\begin{array}{l}\text { I actively contribute to the happiness } \\
\text { and well-being of others }\end{array}$ & $5.45(1.43)$ & 0.48 & $5.99(1.14)$ & 0.48 \\
\hline $\begin{array}{l}\text { I am competent and capable in the } \\
\text { activities that are important to me }\end{array}$ & $6.13(1.13)$ & 0.64 & $6.45(0.72)$ & 0.38 \\
\hline I am a good person and live a good life & $5.72(1.41)$ & 0.80 & $6.18(0.88)$ & 0.78 \\
\hline I am optimistic about my future & $6.01(1.40)$ & 0.74 & $6.19(1.14)$ & 0.66 \\
\hline People respect me & $6.11(1.12)$ & 0.60 & $6.41(0.80)$ & 0.58 \\
\hline Cronbach's alpha & 0.87 & & 0.84 & \\
\hline Mean & 5.66 & & 6.07 & \\
\hline SD & 0.99 & & 0.71 & \\
\hline
\end{tabular}

Note. All factor loadings were significant at $\mathrm{p}<.001$.

\subsection{Factorial Validity}

Before conducting CFA to confirm the factor structure of the FS, data of both student sample and employee sample were checked for normality distribution assumption. The assumption of normality in both samples was satisfied. The absolute values of skewness (students $=1.89$ and employees $=2.23)$ and kurtosis (student $=3.48$ and employee $=3.41$ ) for all items in both samples did not exceed 3 and 10, respectively (Kline, 2005). Thus, CFA was conducted using maximum likelihood estimation method to evaluate the one-factor structure of the Arabic version of the FS.

Model fit was assessed with the following indices: Goodness of Fit Index (GFI), Comparative Fit Index (CFI), Standardized Root Mean Square Residual (SRMR), and Root Mean Square Error of Approximation (RMSEA) with a $90 \%$ confidence interval $(90 \% \mathrm{CI})$. The cut-off values for evaluating whether the model fits the data well were: GFI, CFI $\geq .90$, and SRMR, RMSEA $\leq .08$ (Browne \& Cudeck, 1993; Byrne, 2016; Hu \& Bentler, 1999).

In the student sample, the one-factor model of the FS obtained good fit indices (GFI $=0.96, \mathrm{CFI}=0.95$, SRMR 
$=0.03$, RMSEA $=0.08[90 \% \mathrm{CI}=0.077-0.101)$. The results also showed a good fit between the data and one-factor model of the FS for employee sample (GFI $=0.95, \mathrm{CFI}=0.95$, SRMR $=0.04, \mathrm{RMSEA}=0.08[90 \%$ $\mathrm{CI}=0.057-0.105])$. The standardized factor loadings are shown in Table 1. All factor loadings were significant at $\mathrm{p}<.001$, ranging from 0.48 to .80 in the student sample, and from 0.38 to 0.78 in the employee sample. These results confirmed the one-factor structure of the FS in an Arabic cultural context.

\subsection{Measurement Invariance}

After verifying the factor structure of the FS, the measurement invariance for the one-factor model across study sample groups (students and employees) was tested using MGCFA. Three different levels of invariance were sequentially tested: configural, metric, and scalar invariance. Configural invariance tests whether the one-factor model is observed between comparison groups. Metric invariance tests the equivalence of the factor loadings for each item between groups, implying that students and employees understand and interpret the items similarly. Scalar invariance tests the equivalence of item intercepts and this implies that any differences across groups in the means of the items are a result of true differences in the means of their corresponding construct. The difference in fit indices were used to assess invariance of the one-factor model across groups. A change in CFI $(\triangle \mathrm{CFI})$ of less than 0.010 with a change in RMSEA ( $\triangle \mathrm{RMSEA}$ ) of less than 0.015 or a change in SRMR ( $\triangle$ SRMR) of less than 0.030 suggest evidence of invariance (Byrne \& van de Vijver, 2010; Chen, 2007). Results of invariance analyses are shown in Table 2 . The configural model provided good fit to the data (GFI $=0.96, \mathrm{CFI}$ $=0.95, \mathrm{SRMR}=0.04, \mathrm{RMSEA}=0.06[90 \% \mathrm{CI}=0.054-0.069])$, indicating that the one-factor structure of FS was equal across groups. The metric invariance model was also supported $(\triangle \mathrm{CFI}=.008, \Delta \mathrm{RMSEA}=.000$, $\triangle \mathrm{SRMR}=.026)$, but the scalar invariance model did not hold $(\triangle \mathrm{CFI}=.011, \Delta \mathrm{RMSEA}=.005, \Delta \mathrm{SRMR}=.076)$.

Table 2. Measurement invariance of the Arabic Flourishing Scale across study samples

\begin{tabular}{|c|c|c|c|c|c|c|c|c|}
\hline \multirow[b]{2}{*}{ Model } & \multicolumn{4}{|c|}{ Overall fit indices } & \multicolumn{4}{|c|}{ Comparative fit indices } \\
\hline & $\chi^{2}(d f)$ & CFI & RMSEA (90\% CI) & SRMR & $\Delta \chi^{2}(d f)$ & $\Delta \mathrm{CFI}$ & DRMSEA & ASRMR \\
\hline Configural & $230.65(40)$ & 0.952 & $0.061(0.054,0.069)$ & 0.0438 & - & - & - & \\
\hline Metric & $269.14(47)$ & 0.944 & $0.061(0.054,0.068)$ & 0.0699 & $38.49(7)$ & 0.008 & 0.000 & 0.0261 \\
\hline Scalar & $313.73(54)$ & 0.933 & $0.066(0.059,0.073)$ & 0.1457 & $44.59(7)$ & 0.011 & 0.005 & 0.0758 \\
\hline
\end{tabular}

Note. $d f=$ degrees of freedom; CFI = comparative fit index; RMSEA= root mean square error of approximation; $\mathrm{CI}=$ confidence interval.

\subsection{Convergent and Discriminant Validity}

Table 3 presents the correlations between the FS and other measures on the full sample of students and employees. Convergent validity was tested by calculating the correlations between the FS and other measures of well-being and happiness: SWLS; Fordyce's single item of happiness, and single item satisfaction with life. As expected, the FS significantly and positively correlated with SWLS $(r=0.73, p<.001)$, happiness $(r=0.64, p$ $<.001)$, and satisfaction with life $(\mathrm{r}=0.65, \mathrm{p}<.001)$. To assess discriminant validity, the FS was correlated with the CES-DS as a measure of depression. The CES-DS demonstrated a negative correlation with the FS ( $r=-0.54$, $\mathrm{p}<.001$ ), supporting the discriminant validity of the FS.

Table 3. Correlations between the Flourishing Scale with other relevant scales (all samples, $\mathrm{N}=1268$ )

\begin{tabular}{lllll}
\hline Measures & FS & SWLS & Happiness & Life Satisfaction \\
\hline SWLS & $0.729 * * *$ & & & \\
Happiness & $0.643 * * *$ & $0.695 * * *$ & & \\
Life Satisfaction & $0.650 * * *$ & $0.745 * * *$ & $0.800^{* * *}$ & \\
CED-DS & $-0.536^{* * *}$ & $-0.558^{* * *}$ & $-0.706 * * *$ & $-0.602 * * *$
\end{tabular}

Note. FS Flourishing Scale, SWLS Satisfaction with Life Scale, CED-DS The Centre of Epidemiological Studies Depression Scale, ${ }^{* *}$ p-value $<0.001 ; * *$ p-value $<0.01 ; *$ p-value $<0.05$.

\section{Discussion}

The aim of the study was to evaluate the psychometric properties and measurement invariance of the Arabic version of the FS in an Arabic context. Data was gathered from two samples, one of university students and one of full-time employees, in Saudi Arabia. The psychometric properties of the Arabic FS were tested for internal consistency, CFA, and convergent and discriminant validity. Results of the reliability analysis displayed that the 
internal consistency estimates for both samples were good. The Arabic FS performed well in terms of convergent and discriminant validity with other scales of well-being, happiness, life satisfaction, and depression. These results are consistent with previous studies (Diener et al., 2010; Duan \& Xie, 2019; Giuntoli et al., 2017).

As in the primary study (Diener et al., 2010), CFA showed a one-factor structure. The one-factor model was also consistent with findings from China (Duan \& Xie, 2019), France (Villieux et al., 2016), Italy (Giuntoli et al., 2017), Japan (Sumi, 2014a), Taiwan (Lin, 2015), Iran (Fassih-Ramandi et al., 2020), Portugal (Silva \& Caetano, 2013), Russia (Didino et al., 2019), Spain (Ramires-Maestre et al., 2017), India (Premchandran \& Priyadarshi, 2018), Egypt (Salama-Younes, 2017), Canada (Romano, Ferro, Patte, Diener, \& Leatherdale, 2020), and New Zealand (Hone, Jorden, \& Schofield, 2014). Results also provided support for full metric measurement invariance between students and employees. This displayed that the one-factor structure of FS was equal throughout all groups and both students and employees understand and interpret the items similarly.

\section{References}

Al-Darmaki, F., Ahammed, S., Hassane, S., Abdullah, S. A., Yaaqeib, S., \& Dodeen, H. (2015). Validation of Arabic State self-esteem and satisfaction with life scales among married individuals from the United Arab Emirates. International Journal of Humanities and Social Science, 5(10), 76-83.

Browne, M., \& Cudeck, R. (1993). Alternative ways of assessing model fit. In K. Bollen \& J. Long (Eds.), Testing structural models (pp. 445-455). Sage.

Byrne, B. M. (2016). Structural equation modeling with AMOS: Basic concepts, applications, and programming. Routledge. https://doi.org/10.4324/9781315757421

Byrne, B. M., \& van de Vijver, F. J. R. (2010). Testing for measurement and structural equivalence in large-scale cross-cultural studies: Addressing the issue of nonequivalence. International Journal of Testing, 10(2), 107-132. https://doi.org/10.1080/15305051003637306

Checa, I., Perales, J., \& Espejo, B. (2018). Spanish validation of the flourishing scale in the general population. Current Psychology, 37, 949-956. https://doi.org/10.1007/s12144-017-9581-0

Chen, F. F. (2007). Sensitivity of goodness of fit indexes to lack of measurement invariance. Structural Equation Modeling: A Multidiscipline Journal, 14, 464-504. https://doi.org/10.1080/10705510701301834

Choudhry, F. R. et al. (2018). Factor structure of Urdu version of the flourishing scale. Frontiers in Psychology, 9, 1513. https://doi.org/10.3389/fpsyg.2018.01513

da Fonseca, P. N., da Silva Nascimento, B., Macedo Barbosa, L. H. G., Vione, K. C., \& Veloso Gouveia, V. (2015). Flourishing scale: Evidence of its suitability to the Brazilian context. Social Inquiry into Well-Being, 1(2), 33-40. https://doi.org/10.13165/SIIW-15-1-2-07

Deci, E. L., \& Ryan, R. M. (2008). Hedonia, eudaimonia, and well-being: An introduction. Journal of Happiness studies, 9, 1-11. https://doi.org/10.1007/s10902-006-9018-1

Didino, D., Taran, E. A., Barysheva, G. A., \& Casati, F. (2019). Psychometric evaluation of the Russian version of the flourishing scale in a sample of older adults living in Siberia. Health and quality of Life Outcomes, 17. https://doi.org/10.1186/s12955-019-1100-6

Diener, E., Emmons, R. A., Larsen, R. J., \& Griffin, S. (1985). The satisfaction with life scale. Journal of Personality Assessment, 49(1), 71-75. https://doi.org/10.1207/s15327752jpa4901_13

Diener, E., Oishi, S., \& Lucas, R. E. (2003). Personality, culture, and subjective well-being: Emotional and cognitive evaluations of life. Annual Review of Psychology, 54, 403-425. https://doi.org/10.1146/annurev.psych.54.101601.145056

Diener, E., Wirtz, D., Tov, W., Kim-Prieto, C., Choi, D. W., Oishi, S. et al. (2010). New well-being measures: Short scales to assess flourishing and positive and negative feelings. Social Indicators research, 97(2), 143-156. https://doi.org/10.1007/s11205-009-9493-y

Duan, W., \& Xie, D. (2019). Measuring adolescent flourishing: Psychometric properties of flourishing scale in a sample of Chinese adolescents. Journal of Psychoeducational Assessment, 37(1), 131-135. https://doi.org/10.1177/0734282916655504

Fassih-Ramandi, Z., Soleimani, M. A., Allen, K. A., Gorgulu, O., \& Motalebi, S. A. (2020). Validity and reliability of the flourishing scale in a sample of older adults in Iran. Clinical Interventions in Aging, 15, 673-681. https://doi.org/10.2147/CIA.S251067 
Fordyce, M. W. (1988). A review of research on happiness measures: A sixty-second index of happiness and mental health. Social Indicators Research, 20,355-381. https://doi.org/10.1007/BF00302333

Giuntoli, L., Ceccarini, F., Sica, C., \& Caudek, C. (2017). Validation of the Italian versions of the flourishing scale and the scale of positive and negative experience. Sage Open, 7, 1-12. https://doi.org/10.1177/2158244016682293

Hone, L., Jorden, A., \& Schofield, G. (2014). Psychometric properties of the flourishing scale in a New Zealand sample. Social Indicators Research, 119, 1031-1045. https://doi.org/10.1007/s11205-013-0501-x

$\mathrm{Hu}, \mathrm{L} .$, \& Bentler, P. (1999). Cutoff criteria for fit indexes in covariance structure analysis: Conventional criteria versus new alternatives. Structural Equation Modeling: A Multidisciplinary Journal, 6(1), 1-55. https://doi.org/10.1080/10705519909540118

Keyes, C. L., Shmotkin, D., \& Ryff, C. D. (2002). Optimizing well-being: The empirical encounter of two traditions. Journal of Personality and Social Psychology, 82, 1007-1022. https://doi.org/10.1037/0022-3514.82.6.1007

Khodarahimi, S. (2013). Hope and flourishing in an Iranian adults sample: Their contributions to the positive and negative emotions. Applied Research Quality Life, 8, 361-372. https://doi.org/10.1007/s11482-012-9192-8

Kline, R. B. (2005). Principles and practice of structural equation modeling. 2nd ed. New York: Guilford.

Lin, C. C. (2015). Validation of the psychological well-being scale for use in Taiwan. Social Behavior and Personality: An International Journal, 43(5), 867-874. https://doi.org/10.2224/sbp.2015.43.5.867

Lyubomirsky, S., \& Lepper, H. S. (1999). A measure of subjective happiness: Preliminary reliability and construct validation. Social Indicators Research, 46, 137-155. https://doi.org/10.1023/A:1006824100041

OECD. (2013). OECD guidelines on measuring subjective well-being. OECD Publishing. https://doi.org/10.1787/9789264191655-en

Pozo-Munoz, C., Garzon-Umerenkova, A., Bretones-Nieto, B., \& Ligia-Charry, C. (2016). Psychometric properties and dimensionality of the "Flourishing Scale" in Spanish-speaking population. Electronic Journal of Research in Educational Psychology, 14(1), 175-192. https://doi.org/10.14204/ejrep.38.15044

Premchandran, R., \& Priyadarshi, P. (2018). Validation of the flourishing scale for married employees in the information technology-enabled services sector in India. Journal of Well-being Assessment, 2, 75-89. https://doi.org/10.1007/s41543-018-0012-2

Putnick, D. L., \& Bornstein, M. H. (2016). Measurement invariance conventions and reporting: The state of the art and future directions for psychological research. Developmental Review, 41, 71-90. https://doi.org/10.1016/j.dr.2016.06.004

Radloff, L. S. (1977). The CES-D scale: A self-report depression scale for research in the general population. Applied Psychological Measurement, 1(3), 385-401. https://doi.org/10.1177/014662167700100306

Ramires-Maestre, C., Correa, M., Rivas, T., Lopez-Martinez, A. E., Serrano-Ibanez, E. R., \& Esteve, R. (2017). Psychometric characteristics of the Flourishing Scale-Spanish Version (FS-SV). The factorial structure in two samples: Students and patients with chronic pain. Personality and Individual Differences, 117, 30-36. https://doi.org/10.1016/j.paid.2017.05.035

Romano, I., Ferro, M. A., Patte, K. A., Diener, E. D., \& Leatherdale, S. T. (2020). Measurement invariance of the flourishing scale among a large sample of Canadian adolescents. International Journal of Environmental Research and Public Health, 17, 7800. https://doi.org/10.3390/ijerph17217800

Ryan, R. M., \& Deci, E. L. (2001). On happiness and human potentials: A review of research on hedonic and eudaimonic wellbeing. Annual Review of Psychology, 52, 141-166. https://doi.org/10.1146/annurev.psych.52.1.141

Ryff, C. D., \& Keyes, C. L. M. (1995). The structure of psychological well-being revisited. Journal of Personality and Social Psychology, 69, 719-727. https://doi.org/10.1037/0022-3514.69.4.719

Salama-Younes, M. (2017). Psychometric properties of the flourishing scale in an Egyptian setting. Journal of Psychology in Africa, 27(4), 310-315. https://doi.org/10.1080/14330237.2017.1347749

Schotanus-Dijkstra, M., ten Klooster, P. M., Drossaert, C. H. C., Pieterse, M. E., Bolier, L., Walburg, J. A. et al. (2016). Validation of the flourishing scale in a sample of people with suboptimal levels of mental well-being. BMC Psychology, 4. https://doi.org/10.1186/s40359-016-0116-5 
Seligman, M. E. (2011). Flourishing: A visionary new understanding of happiness and well-being. New York: Simon \& Schuster.

Seligman, M. E., \& Csikszentmihalyi, M. (2000). Positive psychology: An introduction. American Psychologist, 55(1), 5-14. https://doi.org/10.1037/0003-066X.55.1.5

Silva, A. J., \& Caetano, A. (2013). Validation of the Flourishing Scale and scale of positive and negative experience in Portugal. Social Indicators Research, 110(2), 469-478. https://doi.org/10.1007/s11205-011-9938-y

Sumi, K. (2014a). Reliability and validity of Japanese versions of the Flourishing scale and the scale of positive and negative experience. Social Indicators Research, 118, 601-615. https://doi.org/10.1007/s11205-013-0432-6

Sumi, K. (2014b). Temporal stability of the Japanese versions of the flourishing scale and the scale of positive and negative experience. Journal of Psychology \& Psychotherapy, 4(2). https://doi.org/10.4172/2161-0487.1000140

Tang, X., Duan, W., Wang, Z., \& Liu, T. (2016). Psychometric evaluation of the simplified Chinese version of flourishing scale. Research on Social Practice, 26(5), 591-599. https://doi.org/10.1177/1049731514557832

Tong, K. K., \& Wang, Y. Y. (2017). Validation of the flourishing scale and scale of positive and negative experience in a Chinese community sample. PLoS ONE, 12(8), e0181616. https://doi.org/10.1371/journal.pone.0181616

Villieux, A., Sovet, L., Jung, S. C., \& Guilbert, L. (2016). Psychological flourishing: Validation of the French version of the flourishing scale and exploration of its relationships with personality traits. Personality and Individual Differences, 88, 1-5. https://doi.org/10.1016/j.paid.2015.08.027

Waterman, A. S. (2008). Reconsidering happiness: A eudaimonist's perspective. Journal of Positive Psychology, 3, 234-252. https://doi.org/10.1080/17439760802303002

Watson, D., Clark, I. A., \& Tellegen, A. (1988). Development and validation of brief measures of positive and negative affect: The PANAS scales. Journal of Personalitiy and Social Psychology, 54, 1063-1070. https://doi.org/10.1037/0022-3514.54.6.1063 


\section{Appendix}

The Arabic version of the Flourishing Scale

7-point Likert scale:

\begin{tabular}{|c|c|c|}
\hline Original English version & Arabic version & \\
\hline 1- $\quad$ Strongly disagree & غير موافق على الإطلاق & -1 \\
\hline 2- Disagree & غير موافق & -2 \\
\hline 3- Slightly disagree & غير مو افق إلى حد ما & -3 \\
\hline 4- $\quad$ Mixed or neither agree nor disagree & محايد أو لست مو افق ولست معارض & -4 \\
\hline 5- Slightly agree & مو افق إلى حد ما & -5 \\
\hline 6- $\quad$ Agree & 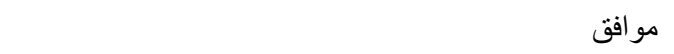 & -6 \\
\hline 7- $\quad$ Strongly agree & مو افق جداً & -7 \\
\hline
\end{tabular}

\section{Items}

\begin{tabular}{|c|c|c|}
\hline Original English version & Arabic version & \\
\hline 1- $\quad$ I lead a purposeful and meaningful life. & أعيش حياة هادفة وذات معنى. & -1 \\
\hline 2- $\quad$ My social relationships are supportive and rewarding. & علاقاتي الاجتماعية داعمة ومجزية. & -2 \\
\hline 3- I am engaged and interested in my daily activities. & أستمتع واهتم بأنشطتي اليومية. & -3 \\
\hline 4- I actively contribute to the happiness and well-being of others. & أساهم بنشاط من أجل سعادة ورفاهية الاخرين. & -4 \\
\hline 5- I am competent and capable in the activities that are important to me. & أنا كفوء وقادر على أداء الأنشطة المهمة بالنسبة لي. & -5 \\
\hline 6- I am good person and live a good life. & أنا شخص جيد و أعيش حياة جيدة. & -6 \\
\hline 7- $\quad$ I am optimistic about my future. & أنا متفائل بمستقبلي. & -7 \\
\hline 8- People respect me. & 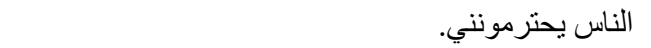 & -8 \\
\hline
\end{tabular}

\section{Copyrights}

Copyright for this article is retained by the author(s), with first publication rights granted to the journal.

This is an open-access article distributed under the terms and conditions of the Creative Commons Attribution license (http://creativecommons.org/licenses/by/4.0/). 